\title{
Evaluation of Factors Affecting Pregnancy Rate after Cervical Insemination of Dairy Ewes in Greece
}

\begin{abstract}
Keywords: Sheep; Insemination; Fertility; Body condition score; Factors

Abstract

The objective of this study was to assess the factors affecting success of cervical Artificial Insemination (Al) with chilled semen in intensively reared dairy ewes in Greece. The study involved 1,785 adult ewes from 20 flocks of Lacaune and Chios sheep. A typical estrous synchronization protocol, including intravaginal placement of progestogen sponge for 14 days and injection of equine chorionic gonadotropin at sponge removal was applied in ewes during mating period. All ewes were cervically inseminated 53-57 hours after sponge removal with chilled semen $(150 C)$ collected from 10 adult purebred Lacaune rams. Pregnancy Diagnosis (PD) was performed by trans-dermal ultrasonography at 35 $38 \mathrm{~d}$ after Al. The following data were available for each ewe: breed parity; Body Condition Score (BCS) at sponge placement, at $\mathrm{Al}$ and at PD; presence of rams during synchronization and number of previous synchronizations. Recordings during the Al procedure included: onse of synchronization to Al interval; semen collection to Al interval; semen deposition depth; cervical mucus presence; order of ewe; average time required for each animal; ram semen used. The results showed that farm, parity, semen deposition depth, ram, ewe BCS and changes of BCS during the sponge placement-PD period, significantly affected Al success $(P<0.05)$. Overall fertility was $44 \%$. Ewes of 2 nd $(50.3 \%)$ and 3rd lactation $(48.1 \%$ ) had the highest conception rates, that declined as age increased. Ewes in moderate BCS (2.50-3.50) at onset of synchronization $(48.4 \%)$ and $\mathrm{Al}(49.4 \%)$ had significantly higher fertility than ewes with low $(<2.50)$ or high $(>3.50)$ BCS. Positive energy balance following the onset of synchronization seems to benefit animals with low and moderate BCS, but decrease pregnancy rates of high BCS ewes. In conclusion, selection of appropriate ewes and rams, BCS evaluation prior to synchronization and adjustment of dietary management are key factors dictating pregnancy rates following $\mathrm{Al}$ in greek dairy sheep.
\end{abstract}

\section{Introduction}

Assisted reproductive technologies in farm animals are used to cater the needs for higher productivity and better quality of products In sheep production, the use of Artificial Insemination (AI) has enabled the rapid introduction of valuable genes that improved production traits and prevented disease transmission [1].

However, in comparison to other food producing animals, the implementation of AI in sheep globally, is relatively limited $[2,3]$. The only exception is France, where more than 410,000 inseminations are performed annually in both nucleus and commercial dairy flocks of the Lacaune breed [4]. An obstacle to the widespread use of AI in sheep is the structural complexity of the ewe cervix that prevents deep deposition of semen in uterus and leads to poor fertility rates when frozen-thawed semen is used for cervical AI $[5,6]$. The notion is that fertility rates can be enhanced by the application of laparoscopic insemination, but the procedure has increased costs, requires personnel with technical skills and raises welfare concerns. Using chilled semen for cervical AI enhances fertility, but increases semen production cost, has time limitations during transportation and often
Journal of

Veterinary Science \& Medicine

\author{
Priskas S, Termatzidou SA, Gargani S, Arsenos G \\ Laboratory of Animal Husbandry, Aristotle University of \\ Thessaloniki, Greece
}

\section{*Address for Correspondence}

Priskas S, Faculty of Veterinary Medicine, Laboratory of Animal Husbandry, School of Health Sciences, Aristotle University of Thessaloniki, 54124, Greece; E-mail: stpriskas@vet.auth.gr

Submission: 04-November, 2019

Accepted: 09-December-2019

Published: 11-December-2019

Copyright: () 2019 Priskas S, et al. This is an open access article distributed under the Creative Commons Attribution License, which permits unrestricted use, distribution, and reproduction in any medium, provided the original work is properly cited.

gives irregular results, since the success of the method is affected by many factors. Environmental conditions, management factors, health of males and females and physiological status of ewes are among the factors that need to be controlled before $\mathrm{AI}$ implementation [7-11].

Dairy sheep industry is of significant importance to national economy of most Mediterranean countries and Greece is one of them [12]. With around 6.6 million milking sheep, Greece is ranking $2^{\text {nd }}$ on milking sheep population and 1st on ewe milk production (670,000 tons)inside EU28, comprising the $45 \%$ of national milk production [13]. Despite its importance, greek dairy sheep industry is characterized by relatively low productivity and is in a transitional phase of gradual intensification [14]. Usage of higher milk-production breeds, like the native Chios and the imported Lacaune breed, and application of better management techniques are becoming more common among farms. Nevertheless, application of AI for the genetic improvement of the animals is not used often and, despite the fact that some breeding programs are in operation, they are supported on the usage of home-bred or imported rams [15]. Although AI is commercially available in most areas, the high irregularity on fertility results makes difficult its widespread application.

Our objective was to carry out an artificial insemination programme to study the factors affecting the success of cervical Artificial Insemination (AI) with chilled semen in intensively reared dairy ewes in Greece. It is the first study that assesses the effect of female, ram, AI procedure conditions and farm nutrition program at the same time on fertility rates after AI on intensively reared dairy sheep in the area.

\section{Materials and Methods}

\section{Animals}

The study was conducted during the usual breeding season in Greece, from May to November, for two consecutive years (20172018). A total of 1785 adult ewes (1247 Lacaune and 538 Chios) were used from 20 commercial flocks located in North and Central region of Greece. Selected ewes belong to the most common intensively reared breeds in Greece and were born and raised in the above regions. During the study, the animals were at the $5-7^{\text {th }}$ month of their lactation with an average daily milk yield of $1.32 \pm 0.22$ liters. 


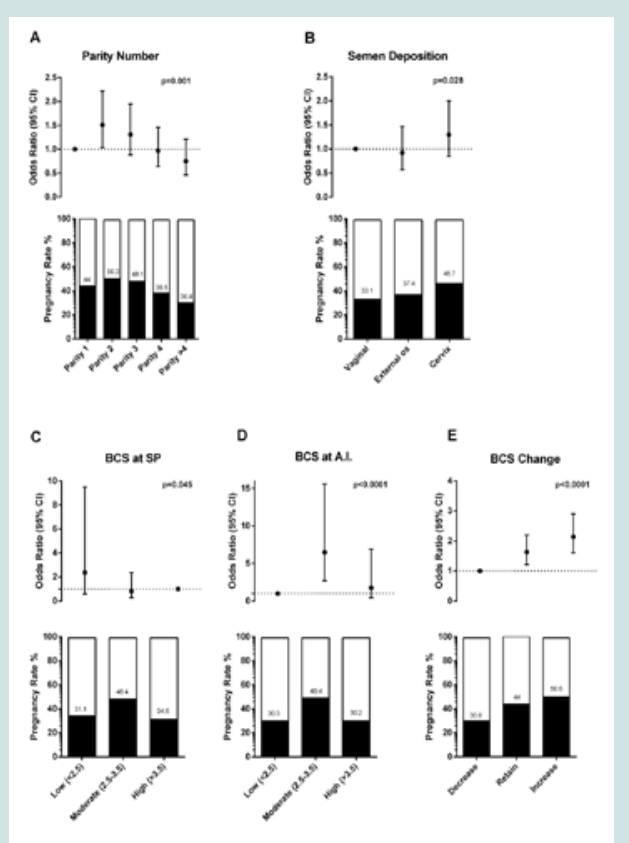

Figure 1: Pregnancy rates and adjusted odds ratio with 95\% Confidence Interval of significant factors in final model: parity number (A), semen deposition site (B), $B C S$ at $S P(C), B C S$ at $A I(D), B C S$ change $(E)$.

Ewes received rations containing mainly alfalfa hay and alfalfa silage, supplemented with $0.800-1.400 \mathrm{~kg}$. Of a concentrate mix of maize, soybean meal, barley and wheat middlings depending on their milk production. Ewes had free access to water and wheat straw that was offered ad-libitum in all cases.

\section{Estrous synchronization}

Each ewe was treated with a sponge containing $20 \mathrm{mg}$ Fluogestone Acetate (FGA) (CHRONOGEST CR ${ }^{\circ}$, MSD Animal Health), that was placed intravaginally for 14 days. At the day of sponge withdrawal, 500 IU (Lacaune) or 400 IU (Chios) of equine Chorionic Gonadotropin (eCG) (GONASER ${ }^{\star}$, Hipra) were intramuscularly injected to the ewes.

\section{AI procedure}

Semen was collected from 10 Lacaune rams that were located in the same semen collection center (OVIS PC, Greece), using an artificial vagina. Immediately after collection, motility and concentration of the undiluted semen were assessed. Only ejaculates with concentration greater than $3 \times 10^{9}$ spermatozoa/ml and mass motility greater than 4 , on the 0-5 scale described by Evans and Maxwell were used for the study [16]. After this evaluation, semen was diluted to concentration of 1,6x109 spermatozoa/ml using skimmed milk supplemented with antibiotics gradually cooled at $15{ }^{\circ} \mathrm{C}$ and loaded into $0,25 \mathrm{ml}$ mini straws (400x106 spz/ dose) (IMV Technologies, France) [17]. The straws were transported on farm for use inside thermos flasks with acetic acid ampoules at $15^{\circ} \mathrm{C}$.

Cervical fixed-time AI was performed on each farm 53-57 hours after the sponge removal. Ewes were immobilized by two assistants, with hind legs lifted. In case of mucus presence inside vagina, the animal was put again in horizontal position and the mucus was removed using a speculum. AI was performed afterwards with the help of a speculum equipped with light source and an ovine AI gun (IMV Technologies, France). All artificial inseminations were carried out by the same technician within 8 hours after semen collection. During the procedure, ewes were kept on a restrained area and released to their boxes after insemination, or they were head-locked in feed alley whenever this was applicable Ultrasonography was performed 35-38 days after AI for Pregnancy Diagnosis (PD) using 5MHztransducerwith sector probe (ANIMAL PROFI, DRAMINSKI, Poland).

\section{Data collection}

For all inseminated ewes, data concerning breed, parity and number of previous synchronizations were recorded. Body Condition Score (BCS) was assessed for each ewe at the time of sponge placement, $\mathrm{AI}$ and PD. BCS was assessed by palpation in the lumbar region by the same experienced evaluator. Scores assigned to the ewes were based on the existing scale of Russel et al. ranging from 0 to 5, according to which score (0) represents extremely emaciated animals, while the highest score (5) represents obese ones [18]; 0.25 and 0.5 unit increments were used. Changes of BCS between sponge placement and pregnancy diagnosis (51-54 days) were evaluated to determine whether the animals were in negative, zero or positive energy balance during that period.

At the time of AI, the following data were collected for each ewe: ram semen identification, semen collection-AI interval, sponge removal-AI interval, time required per $\mathrm{AI}$, order number of the $\mathrm{AI}$, presence of mucus in vagina, availability of headlocks for the procedure, presence of rams near the females during synchronization period and semen deposition site. The latter was distinguished in 3 classes depending on the deposition depth of the catheter and retrograde flow of semen: vaginal deposition, external cervical os deposition with partial semen backflow or deeper cervical placement 
Citation: Priskas S, Termatzidou SA, Gargani S, Arsenos G. Evaluation of Factors Affecting Pregnancy Rate after Cervical Insemination of Dairy Ewes in Greece. J Veter Sci Med. 2019;7(2): 7.

ISSN: $2325-4645$

Table 1: Description of risk factors assessed in the analysis.

\begin{tabular}{|c|c|c|c|c|c|}
\hline \multirow{2}{*}{$\begin{array}{c}\text { Risk Factors } \\
\text { Farm }\end{array}$} & \multirow{2}{*}{$\begin{array}{c}\text { Class } \\
20 \text { classes }\end{array}$} & \multirow{2}{*}{$\frac{\mathbf{N}}{1.845}$} & \multirow[t]{2}{*}{ Mean } & \multicolumn{2}{|c|}{ Included in full model } \\
\hline & & & & YES & $* * *$ \\
\hline \multirow[t]{2}{*}{ Year } & 1 & 869 & & NO & n.s. \\
\hline & 2 & 916 & & & \\
\hline \multirow[t]{6}{*}{ Month } & May & 414 & & YES & ** \\
\hline & June & 370 & & & \\
\hline & July & 89 & & & \\
\hline & September & 503 & & & \\
\hline & October & 209 & & & \\
\hline & November & 112 & & & \\
\hline \multirow[t]{2}{*}{ Breed } & Lacaune & 1247 & & YES & $* * *$ \\
\hline & Chios & 538 & & & \\
\hline \multirow[t]{4}{*}{ Parity } & 1 & 175 & $2.99 \pm 1.17$ & YES & $* * *$ \\
\hline & 2 & 505 & & & \\
\hline & 4 & 418 & & & \\
\hline & $>4$ & 207 & & & \\
\hline \multirow[t]{3}{*}{ BCS at SP } & Low $(<2.5)$ & 295 & $2.99 \pm 0.6$ & YES & $* * *$ \\
\hline & Moderate (2.5-3.5) & 1278 & & & \\
\hline & High (>3.5) & 212 & & & \\
\hline \multirow[t]{6}{*}{ BCS at A.I. } & Low $(<2.5)$ & 284 & $3.01 \pm 0.59$ & YES & $* * *$ \\
\hline & Moderate (2.5-3.5) & 1286 & & & \\
\hline & High (>3.5) & 215 & & & \\
\hline & BCS decrease & 393 & & YES & $* * *$ \\
\hline & BCS retain & 589 & & & \\
\hline & BCS increase & 803 & & & \\
\hline \multirow{6}{*}{ Semen deposition depth } & $1(1-25)$ & 500 & & NO & N.S \\
\hline & $2(26-50)$ & 484 & & & \\
\hline & $3(51-75)$ & 429 & & & \\
\hline & Vagina & 118 & & YES & $* * *$ \\
\hline & External os & 343 & & & \\
\hline & Cervix & 1325 & & & \\
\hline \multirow{2}{*}{ Mucus presence } & No & 1340 & & NO & N.S \\
\hline & Yes & 445 & & & \\
\hline \multirow{2}{*}{ Previous eCG administration } & No & 1523 & & YES & * \\
\hline & Yes & 262 & & & \\
\hline \multirow{2}{*}{ Sponge removal to A.I. interval } & $<55$ hours & 447 & $54.98 \pm 0.7$ & & $* * *$ \\
\hline & 55 hours & 918 & & & \\
\hline & $\geq 56$ hours & 420 & & & \\
\hline \multirow{3}{*}{ Semen collection to A.I. interval } & $<4$ hours & 435 & $4.58 \pm 1.18$ & YES & $* * *$ \\
\hline & 4-6 hours & 1222 & & & \\
\hline & $>6$ hours & 128 & & & \\
\hline A.l. speed & & & \multirow{2}{*}{$67.00 \pm 12.84$} & \multirow{2}{*}{ YES } & \multirow{2}{*}{ * } \\
\hline sec/ animal & & & & & \\
\hline \multirow{2}{*}{ Headlocks } & No & 1167 & & NO & N.S \\
\hline & Yes & 502 & & & \\
\hline Precence of rame & No & 1379 & & YES & $* * *$ \\
\hline Presence of rams & Yes & 406 & & & \\
\hline Ram used & 10 classes & & & YES & $* * *$ \\
\hline
\end{tabular}

N.S: Not significant $P \geq 0.25,{ }^{*}: P<0.25,{ }^{* *}: P<0.05,{ }^{* * *}: P<0.01$

without semen backflow.

\section{Statistical analysis}

Binary logistic regression analysis (SPSS ver. 25.0, IBM) was used to determine the effect of risk factors to fertility of AI.

Pregnancy diagnosis outcome at ultrasonography was used as the dependant variable. Logistic regression was conducted according to the method of Hosmer and Lemeshow with the following five steps: 1) preliminary screening of all variables for univariate associations, 2) construction of a full model using all the variables 
Table 2: Semen deposition site and pregnancy rate in Lacaune and Chios ewes.

\begin{tabular}{|c|c|c|c|c|}
\hline \multirow{3}{*}{ Breed } & \multicolumn{3}{|c|}{ Semen deposition site } & \multirow{3}{*}{ Pregnancy rate $(\%)$} \\
\hline & \multicolumn{3}{|c|}{$\%$ (No. ewes) } & \\
\hline & Vagina & External os & Cervix & \\
\hline Lacaune & $5.1 \%(63)^{a}$ & $16.4 \%(205)^{a}$ & $78.5 \%(979)^{a}$ & 48.3 \\
\hline Chios & $10.2 \%(55)^{b}$ & $25.5 \%(137)^{\mathrm{b}}$ & $64.3 \%(346)^{b}$ & 34.2 \\
\hline
\end{tabular}

Different superscripts within same column indicate significant differences $(P<0.05)$

Table 3: Effect of BCS change on pregnancy rates of animals with different BCS.

\begin{tabular}{|c|c|c|c|c|c|}
\hline \multirow{2}{*}{} & \multicolumn{3}{|c|}{ BCS at sponge placement } & \multicolumn{2}{c|}{ BCS at A.I. } \\
\cline { 2 - 5 } & $<2.5$ & $2.5-3.5$ & $>3.5$ & 2.5 & $<-3.5$ \\
\hline BCS decrease & $0 \%^{\mathrm{a}}$ & $31.1 \%^{\mathrm{b}}$ & $43.5 \%^{\mathrm{b}}$ & $0 \%^{\mathrm{a}}$ & $32.8 \%^{\mathrm{b}}$ \\
\hline BCS retain & $13.5 \%^{\mathrm{a}}$ & $54.2 \%^{\mathrm{b}}$ & $26.2 \%^{\mathrm{a}}$ & $13.3 \%^{\mathrm{a}}$ & $54.2 \%^{\mathrm{b}}$ \\
\hline BCS increase & $48.4 \%^{\mathrm{a}}$ & $53.0 \%^{\mathrm{a}}$ & $22.2 \%^{\mathrm{b}}$ & $45.5 \%^{\mathrm{a}}$ & $26.4 \%^{\mathrm{a}}$ \\
\hline
\end{tabular}

Different superscripts between different columns indicate significant differences $(P<0.05)$

found to be significant in the univariate analysis at $\mathrm{P}<0.25$ level, 3) stepwise removal of nonsignificant variables from the full model and comparison of the reduced model with the previous model for model fit and confounding, 4) evaluation of interactions among variables and 5) assessment of model fit using Hosmer-Lemeshow statistics until all the main effects or interactions were significant at $\mathrm{P}<0.05$ Chi square test was used to compare classes of the variables for better interpretation of the results if required [19].

\section{Results}

The description of examined factors included in univariate analysis as well as in the multivariate model is presented in (Table 1). Among these factors, ewe parity number, semen deposition site, BCS at sponge placement and AI, BCS change from sponge placement to pregnancy diagnosis, farm and ram used had a significant effect on conception rates.

The overall pregnancy rate was $44 \%$. Ewes that were on their second lactation period showed to have higher fertility rates $(50.3 \%)$ compared to the rest, while odds were decreasing as the age increased (Figure 1A). Pregnancy rates increased as the deposition depth increased from vagina (33.1\%) to external cervical os (37.4\%) and to inside cervix (46.7\%) (Figure 1B). The depth of semen deposition was found to differ significant between the 2 breeds (Table 2). Although breed was found to have a significant effect on fertility in the univariate analysis, it was not included in the final regression model $(P>0.05)$.

Higher fertility rates were observed at animals with moderate BCS (2.5-3.5) at sponge placement and at time of A.I (Figure 1C and 1D). Conception rate odds ratio of ewes increasing or retaining their BCS were 2.14 and 1.63 times to ewes in negative energy balance respectively (Figure 1E). However, at first step, interactions were found between BCS at sponge placement and BCS change as well as between BCS at A.I. and BCS change on their effect on conception rates. Fertility was increased only in animals with low (45.5\%) or moderate $(54.1 \%)$ BCS when they restored their body reserves. On contrast, fertility rates were low when high BCS animals gained more weight $(22.2 \%)$ (Table 3$)$. The effect of these interactions was significant on the fertility of the animals in the univariate model $(\mathrm{p}<0.25)$, but the interactions were (Hosmer and Lemeshow test $=10.62 ; \mathrm{df}=8 ; \mathrm{P}=0.224$; Classification accuracy $=64.9 \%$ ) finally excluded from the final model as non-significant. No other significant interactions between variables were found.
Regarding the rest factors in the final model, pregnancy rates were found to differ significant between farms $(\mathrm{p}<0.001)$ and used rams $(\mathrm{p}=0.007)$.

\section{Discussion}

The present study addressed the main factors affecting fertility after AI using chilled semen in the most common intensively reared dairy breeds in Greece, Chios and Lacaune. It is the first study to examine the application of AI in Greece, including females of a native and foreign breed, born in the area and well adapted in local conditions and management systems.

Ewe parity and age have been widely assessed as factors influencing fertility. Shackell et al. reported a 3\% decrease of fertility per year as average ewe age increased. Similar were the findings of Arranz et al. [20,21], Fukui et al [22], and Palacin et al. [23], who regarded the reduced fertility of older ewes as consequence of the decreased quality of ovulated oocytes, despite the improved cervical penetration that comes with increasing parity $[24,25]$. In our study, pregnancy rates of primiparous ewes were lower compared to ewes at second lactation period and declined rapidly beyond $4^{\text {th }}$ parity. According to Anel et al. [7], young ewes show reduced fertility due to their inclusion with older ewes that usually lamb earlier. Additionally, nutritional deficiencies are often observed in young ewes during the mating period as a result of their larger requirements for growth. Our findings are in contrast with other studies that found no effect of ewe age on their fertility [26,27].

The deposition site of semen into female's reproductive canal is considered very important factor by many authors. In our study, conception rates were improved when semen was deposited inside cervix without semen backflow. The deeper deposition allows more semen to reach the fertilization site and increases pregnancy chances $[28,29]$. However, Paulenz et al. and Masoudi et al. found no difference in pregnancy rates between vaginal and cervical AI when fresh semen was used, stating that fresh semen contains enough motile spermatozoa able to reach fertilization site. Conclusions of Richardson et al. were the same using frozen-thawed semen, but with lower pregnancy rates [30-32]. Attempts to deposit semen deeper in the cervix with the use of specific catheters increase conception rates of fresh semen especially when the catheter was introduced beyond $4 \mathrm{~cm}$ [33]. However, Kaabi indicated that pregnancy rates increased with deposition of semen in cervix up to $3 \mathrm{~cm}$, but deeper deposition decreases fertility, maybe due to catheter and cervical manipulations 
that could activate pathways that interrupt pregnancy [34,35].

Reproductive performance is affected by the nutritional status of animals. Our findings are in agreement with other studies according to which animals in good condition respond well in onset of breeding season and have higher ovulation and lambing rates [22,36]. At the same time, ewes with low BCS activate their ovulation potential less effectively [26,37]. However, there seems to be a plateau on the effect of BCS on fertility as there is no benefit of increased BCS beyond a point, and conception rates decline in animals with BCS> 3.5. Very fat animals fail to show estrous at predicted time and exhibit lower lambing rate potential [38-40]. Our study agrees with many authors ending up that ewes should have a BCS of 2.5-3.5 at mating period $[22,41,42]$.

A positive effect of BCS increase on fertility of animals with low and medium BCS was indicated in our study. Flushing during premating period has positive effect on conception rates and can modify the number and quality of embryos especially on thin ewes $[43,44]$. At the same time, low feed intake and BCS reduction results to lower ovulation rate, decreased embryonic growth and increased fetal losses [45-47]. Negative energy balance seems to have no significant effect on animals with high BCS, indicating that the endocrine response to undernutrition depends on body energy reserves [48]. However, ewes with BCS $>3.5$ demonstrated a decrease in pregnancy rate when they were on positive energy balance. We suggest that weight gain should be discouraged in fat sheep as can cause high ovulation rates and increase embryonic losses [49].

Pregnancy rates of AI tended to be different among the farms in our study. This could be attributed to variations on reproductive planning and animal handling between farms [7], human-animal interactions [23], or other stressful management conditions that suppress fertility [50]. According to Santolaria et al. [10], fertility rates can be affected positively by the improvement of handling conditions in the farms.

Ram affected conception rates significantly, despite the strictly selection of the ejaculates. Ram effect on AI success, evaluated independently from the quality of the ejaculate, has been described by many authors $[23,51]$. It remains unclear why same quality semen produced from different rams and processed under the same conditions, show significant variations in fertility rates. Differences on seminal characteristics of the ejaculate that remain uncertain or even genetic factors that influence ram's fertility could have been responsible for these variations.

Ewe breed has been described as a significant factor affecting AI success by many authors $[6,8,26]$. Most studies are focused on the differences among breeds on ovulation time, cervix morphology or physicochemical properties of cervical mucus that can impair semen transport $[28,52,53]$. In our study, breed did not affected pregnancy rates significantly. However, we reported significant differences on the deposition site of the semen between Chios and Lacaune breed. This observation can be explained by the differences on cervix morphology between the two breeds and could be responsible for pregnancy rates differences observed.

The month of the insemination performance had no effect on pregnancy rates, mainly due to the fact that this study was conducted from May to November, when both breeds exhibit strong cyclic activity in this region. The lack of obvious heat stress effect during July and August that could affect reproductive efficiency indicates the need of evaluating more precisely the micro-environmental conditions of each farm [54].

The presence of rams in the area near the synchronized ewes is a factor that could affect pregnancy rates. Lucidi et al. found increased pregnancy rate in Italian breed ewes that were exposed in ram after sponge removal [55]. Exposure of females to rams before sponge removal could reduce ecG administration-onset of estrous interval and reduce the success of classic fixed time insemination protocols $[42,56,57]$. That could be overcome by inseminating the ewes earlier. In our study, rams presence near the ewes during synchronization didn't have any effect to fertility rates. This could be due to the fact that rams didn't join ewes inside their lot, but were kept in a nearby area, limiting thus the male effect of a direct contact.

\section{Conclusion}

In conclusion, farm, ewe parity, semen deposition site, ram and BCS of ewes, as well as changes of it during the period around AI, were the main factors affecting fertility after AI on intensively reared dairy sheep of Greece. Targeted selection of ewes, evaluation of farm's management practices and nutrition program, as well as timely identification of the most fertile rams could lead to better and more consistent results, contributing to the spread of AI application in greek intensive flocks in larger scale.

\section{References}

1. Faigl V, Vass N, Javor A, Kulcsar M, Solti L, et al. (2012) Artificial insemination of small ruminants-a review. Acta Veterinaria Hungarica 60: 115-129.

2. Anel L, Alvarez M, Martinez-Pastor F, García-Macias V, Anel E, et al. (2006) Improvement strategies in ovine artificial insemination. Reprod Dom Anim 41: 30-42.

3. FAO commission on genetic resources for food and agriculture (2015) The second report on the state of the world's animal genetic resources for food and agriculture.

4. Barillet F, Marie C, Jacquin M, Lagriffoul G, Astruc JM (2001) The French Lacaune dairy sheep breed: use in France and abroad in the last 40 years. Livestock Production Science 71: 17-29.

5. Halbert GW, Dobson H, Walton JS, Buckrell BC (1990) The structure of the cervical canal of the ewe. Theriogenology 33: 977-992.

6. Salamon S, Maxwell WMC (1995) Frozen storage of ram semen. II. Causes of low fertility after cervical insemination and methods of improvement. Anim Reprod Sci 38: 1-36.

7. Anel L, Kaabi M, Abroug B, Alvarez M, Anel E, et al. (2005) Factor influencing the success of vaginal and laparoscopic artificial insemination in Churra ewes: a field assay. Theriogenology 63: 1235-1247.

8. Donovan A, Hanrahan JP, Kummen E, Duffy P, Boland MP (2004) Fertility in the ewe following cervical insemination with fresh or frozen-thawed semen at a natural or synchronized oestrus. Anim Reprod Sci 84: 359-368.

9. David I, Robert-Granie C, Manfredi E, Lagriffoul G, Bodin L (2008) Environmental and genetic variation factors of artificial insemination success in French dairy sheep. Animal 2: 979-986.

10. Santolaria P, Palacin I, Yániz JL (2011) Management factors affecting fertility in sheep. In: Manafi M. Artificial insemination in farm animals. INTECH.

11. Abecia JA, Manez J, Macias A, Lavina A, Palacios C (2017) Climate zone influences the effect of temperature on the day of artificial insemination on fertility in two Iberian sheep breeds. Journal of Animal Behaviour and 
Citation: Priskas S, Termatzidou SA, Gargani S, Arsenos G. Evaluation of Factors Affecting Pregnancy Rate after Cervical Insemination of Dairy Ewes in Greece. J Veter Sci Med. 2019;7(2): 7.

Biometeorology 5: 124-131.

12. deRancourt M, Fois N, Lavín MP, Tchakérian E, Vallerand F (2006) Mediterranean sheep and goat production: an uncertain future. Small Rumin Res. 62: 167-179.

13. Eurostat (2018) Agricultural statistics.

14. Valergakis GE, Gelasakis AI, Oikonomou G, Arsenos G, Fortomaris P, et al. (2010) Profitability of a dairy sheep genetic improvement program using artificial insemination. Animal 4: 1628-1633.

15. Gelasakis Al, Valergakis GE, Arsenos G, Banos G (2012) Description and typology of intensive Chios dairy sheep farms in Greece. J Dairy Sci 95 3070-3079.

16. Evans G, Maxwell WMC (1987) Salamon's Artificial Insemination of Sheep and Goats. Butterworths, Sydney 11: 194.

17. Baril G, Chemineau P, Cognie Y, Guerin Y, Leboeuf B, et al. (1993) Training manual for artificial insemination in sheep and goats. FAO 8: 261-273.

18. Russel AJF, Dowey JM, Gunn RG (1969) Subjective assessment of body fat in live sheep. Journal of Agronomical Sciences 72: 451-454.

19. Hosmer DW, Lemeshow S (1989) Applied logistic regression. Wiley New York, USA 13: 307

20. Shackell GH, Kyle B, Littlejohn RP (1990) Factors influencing the success of a large-scale artificial insemination programme in sheep. Proc New Zealand Soc An Prod 50: 427-430.

21. Arranz J, Freret S, Fidelle F, Fatet A, Druart X, et al. (2008) Fertility after artificial insemination in Pyrenean dairy sheep herds: individual and herd factors linked to breeding practices. Renc Rech Ruminants 15: 359-362.

22. Fukui Y, Kohno H, Okabe K, Katsuki S, Yoshizawa M, et al. (2010) Factors affecting the fertility of ewes after intrauterine insemination with frozen thawed semen during non-breeding season. J Reprod Develop 56: 460-466.

23. Palacin I, Yániz JL, Fantova Blasco EME, Quintín-Casorrán FJ, SevillaMur E, et al. (2012) Factors affecting fertility after cervical insemination with cooled semen in meat sheep. Anim Reprod Sci 132: 139-144.

24. Windsor DP (1995) Factors influencing the success of transcervical insemination in Merino ewes. Theriogenology 43: 1009-1018.

25. El Khalil K, Allai L, Fatet A, Benmoula A, Hamidallah N, et al. (2018) Morphometry and depth of inseminating catheter penetration in prolific and non-prolific ewes at different ages: A post mortem study. Anim Reprod Sci 196: 43-47.

26. Aké-Villanueva RJ, Aké-López RJ, Segura-Correa CJ, Magaña-Monforte GN Aké-Villanueva Y (2017) Factors affecting conception rate of hair ewes after laparoscopic insemination with chilled semen under tropical conditions. Smal Ruminant Research 153: 114-117.

27. Naqvi SMK, Maurya VP, Joshi AV, Sharma R, Mittal JP (2002) Production of crossbred lambs through artificial insemination of non-prolific medium size Malpura and Avikalin ewes using fresh diluted semen of prolific micro size Garole rams. Asian-Aust J Anim Sci 15: 633-636.

28. Eppleston J, Salamon S, Moore NW, Evans G (1994) The depth of cervica insemination and site of intrauterine insemination and their relationship to the fertility of frozen-thawed ram semen. Anim Reprod Sci 36: 211-225.

29. Alvarez M (2000) Study of the cervix of oveha churra as a method of improving the vaginal route in artificial insemination. University of Leon, Spain pp: 258.

30. Paulenz H, Adnoy T, Fossen OH, Soderquist L, Berg KA (2002) Effect of deposition site and sperm number on the fertility of sheep inseminated with liquid semen. Vet Rec 150: 299-302.

31. Masoudi R, Zare Shahneh A, Towhidi A, Kohram H, Akbarisharif A, et al. (2017) Fertility response of artificial insemination methods in sheep with fresh and frozen-thawed semen. Cryobiology 74: 77-80.

32. Richardson L, Hanrahan JP, Donovan A, Marti JI, Fair S, et al (2012) Effect of site of deposition on the fertility of sheep inseminated with frozen-thawed semen. Anim Reprod Sci 131: 160-164.
33. Casali R, Pinczak A, Cuadro F, Guillen-Munoz J, Mezzalira A, et al. (2017) Semen deposition by cervical, transcervical and intrauterine route for fixedtime artificial insemination (FTAI) in the ewe. Theriogenology 103: 30-35.

34. Kaabi M (2002) Analysis of morphostructural, instrumental and methodological factors of transcervical insemination in sheep. University of Leon, Spain pp: 214.

35. Wulster-Radcliffe MC, Lewis GS (2002) Development of a new transcervical artificial insemination method for sheep: effects of a new transcervical artificial insemination catheter and traversing the cervix on semen quality and fertility. Theriogenology 58: 1361-1371.

36. Gunn RG, Doney JM, Russel AJF (1969) Fertility in Scottish blackface ewes as influenced by nutrition and body condition at mating. J Agric Sci 73: 289294.

37. Forcada F, Abecia JA, Sierra I (1992) Seasonal-changes in estrus activity and ovulation rate in Rasa-Aragonesa ewes maintained at 2 different body condition levels. Small Ruminant Research 8: 313-324.

38. Rhind SM, Gunn RG, Doney JM, Leslie ID (1984) A note on the reproductive performance of greyface ewes in moderately fat and very fat condition at mating. Anim Sci 38: 305-307

39. Aliyari D, Mahdi Moeini M, Hossein Shahir M, Ali Sirjani M (2012) Effect of Body Condition Score, Live Weight and Age on Reproductive Performance of Afshari Ewes. Asian J Anim Vet Adv 7: 904-909.

40. Vatankhah M, Talebi MA, Zamani F (2012) Relationship between ewe body condition score (BCS) at mating and reproductive and productive traits in Lori-Bakhtiari sheep. Small Ruminant Research 106: 105-109.

41. Kenyon PR (2013) The use of nutrition to increase sheep performance. Rev Cient Prod Anim 15: 63-76.

42. Contreras-Solis I, Vasquez B, Diaz Y, Letelier C, Lopez-Sebastian A, et al. (2009) Efficiency of estrous synchronization in tropical sheep by combining short-interval cloprostenol-based protocols and male effect. Theriogenology 71: 1018-1025

43. National Research Council-NRC (2007) Nutrients requirements of sheep Washington: National Academies Press

44. Rondina D, Galeati G (2010) The interfaces between nutrition and reproduction of domestic small ruminants and their importance for the success in using biotechnologies in breeding. Acta Scientiae Veterinariae 38: 337-369.

45. Rhind SM, McKelvey WAC, McMillen S, Gunn RG, Elston DA (1989) Effect of restricted food intake, before and/ or after mating, on the reproductive performance of Greyface ewes. Animal Production 48: 149-155.

46. Ridler AL, Corner-Thomas RA, Kenyon PR, Griffiths KJ (2017) Investigation of fetal loss in ewe lambs in relation to liveweight changes and progesterone concentrations in early to mid gestation. N Z Vet J 65: 34-38.

47. Abecia JA, Forcada F, Palacin I, Sanchez-Prieto L, Sosa C, et al. (2014) Undernutrition affects embryo quality of superovulated ewes. Zygote 23: 116124

48. Fernandez-Foren A, Sosa C, Abecia JA, Vazquez MI, Forcada F et al. (2019) Dietary restriction in sheep: Uterine functionality in ewes with different body reserves during early gestation. Theriogenology 135: 189-197.

49. Rassu S, Enne G, Ligios S, Molle G (2004) Nutrition and reproduction. In Pulina G, Bencini R (Eds). Dairy sheep nutrition. CABI Publishing.

50. Dobson H, Fergani C, Routly JE, Smith RF (2012) Effects of stress on reproduction in ewes. Anim Reprod Sci 130: 135-140.

51. Windsor DP (1997) Variation between ejaculates in the fertility of frozen ram semen used for cervical insemination of Merino ewes. Animal Reprod Sci 47: 21-29.

52. Kaabi M, Alvarez M, Anel E, Chamorro CA, Boixo JC, de Paz P, Anel L (2006) Influence of breed and age on morphometry and depth of inseminating catheter penetration in the ewe cervix: a postmortem study. Theriogenology 66: 1876-1883.

53. Richardson L, Hanrahan JP, O'Hara L, Donovan A, Fair S, et al. (2011) Ewe 
Citation: Priskas S, Termatzidou SA, Gargani S, Arsenos G. Evaluation of Factors Affecting Pregnancy Rate after Cervical Insemination of Dairy Ewes in Greece. J Veter Sci Med. 2019;7(2): 7.

ISSN: $2325-4645$

breed differences in fertility after cervical Al with frozen-thawed semen and associated differences in sperm penetration and physicochemical properties of cervical mucus. Anim Reprod Sc 129: 37-43.

54. Santolaria P, Yániz J, Fantova E, Vicente-Fiel S, Palacín I (2014) Climate factors affecting fertility after cervical insemination during the first months of the breeding season in Rasa Aragonesa ewes. Int J Biometeorol 58: 16511655.
55. Lucidi P, Barboni B, Mattioli M (2001) Ram induced ovulation to improve artificial insemination efficiency with frozen semen in sheep. Theriogenology 55: 1797-1805.

56. Evans ACO, Duffy P, Crosby TF, Hawken PAR, Boland MP, et al. (2004) Effect of ram exposure at the end of progestagen treatment on estrus synchronization and fertility during the breeding season in ewes. Anim Reprod Sci 84: 349-358.

57. Hawken PAR, Bearda AP, O'Meara CM, Duffy P, Quinn KM, et al. (2005) The effects of ram exposure during progestagen oestrus synchronization and time of ram introduction post progestagen withdrawal on fertility in ewes. Theriogenology 63: 860-871.

\section{Acknowledgment}

This research is carried out / funded in the context of the project "Recording and evaluation of factors affecting artificial insemination success using fresh ram semen in Greek breeding conditions" (MIS 5007366) under the call for proposals "Supporting researchers with emphasis on new researchers" (EDULLL 34). The project is co-financed by Greece and the European Union (European Social Fund-ESF) by the Operational Programme Human Resources Development, Education and Lifelong Learning 2014-2020. 